ZOFIA MITOSEK

Institute of Polish Literature,

University of Warsaw

\title{
THE POINT OF VIEW (IN FOUR WAYS)
}

\author{
Keywords: point of view, Henry James, Włodzimierz Odojewski, Claude Simon, Szczepan \\ Twardoch
}

Słowa kluczowe: punkt widzenia, Henry James, Włodzimierz Odojewski, Claude Simon, Szczepan Twardoch

In 2013 Jarosław Kaczyński announced that after PIS won the election the museum would have to undergo some changes so that it could "express the Polish point of view."

Gazeta Wyborcza, 6 April 2017

The point of view, an everyday life category that started being used in literary studies at the beginning of the $20^{\text {th }}$ century, has gradually become a subject of interest in linguistic and cultural studies as well. These areas of research introduce new terms and methodologies that are then applicable to analysing the point of view. The novel, which was the initial subject of research, is slowly being abandoned in favour of poetry, documents, non-fiction literature, or even scientific discourse, which, during a time of pluralism and relativism, has evolved from a homogeneous whole into a web of various points of view. Research in the scope of literary studies has been enriched by the cognitivist perspective. The definition of the point of view as developed by experts in the field is far from the ideas and praxes of writers at the beginning of the $20^{\text {th }}$ century. A classic, cognitivist explanation of the notion was provided already in 1990 by Jerzy Bartmiński and it reads as follows:

It is a subjective and cultural factor that determines the way of describing the object, including its categorisation, choosing an onomasiological attitude in the act of naming it, and selection of attributes which are assigned to the object in certain statements and preserved in the meaning. The point of view established by the subject therefore exists as a set of directives forming 
the substance and structure of particular words and whole statements; these directives are also the foundation of identifying speech types and lingual styles. ${ }^{1}$

Does a definition of this degree of complexity pertain to so trivial a conversation?

Well, I mean that I somehow feel to-night - on her behalf - too good to be true. She has had her cake; that is she's in the act now of having it, of swallowing the largest and sweetest piece. ${ }^{2}$

What about the terms introduced by $20^{\text {th }}$-century philosophy? In L'Etre et le Néant, ${ }^{3}$ Jean Paul Sartre distinguished être en soi (being-in-itself) from être pour soi (being-for-itself). The contrast between being-in-itself and being-for-itself means perceiving a concrete reality through individuality and describing the world as seen by a specific person - a description that is full of mistakes and expectations - which is far from the ambitions of its sole objective vision as imposed by being-in-itself.

Initially, the point of view category had homogeneous ambitions, insofar as writing techniques were concerned. It was all about intensifying artistic narration - the consciousness and the characters' speech entered the scene of storytelling, thus replacing the omniscient narrator. The characters' perception of the story became a subject of literary works next to the story itself, with perception seen by the reader as a psychological projection. As a result, the individual truth about the world appeared to be a fusion of what was left from an either reliable or unreliable mind. The subjective homogeneity intended by writers was realised by employing various writing techniques, which are the main topic of my study here.

Within the discussion of the point of view in literature, I will focus on four texts whose technique creates an illusion of reality while transforming the literary topic into a riddle to be solved by the reader. I do not intend to create an exhaustive typology of point of view techniques or to consider numerous theoretical approaches to the issue. My aim is to analyse different textual realisations of a technique that has so profoundly influenced the history of the modern and postmodern novel. I shall focus on works of high artistic merit whose authors seemed conscious of the epistemological consequences of their

\footnotetext{
${ }^{1}$ Jerzy Bartmiński, "Punkt widzenia, perspektywa językowa, językowy obraz świata" ["Point of View, Linguistic Perspective, Linguistic Worldview"], in Językowy obraz świata [The Linguistic Worldview], ed. Jerzy Bartmiński, Lublin: Wydawnictwo UMCS, 1990), 169-183. Translation mine - K.P.

${ }^{2}$ Henry James, The Ambassadors. Norton Critical Edition, ed. Stanford Patrick Rosenbaum (New York: Norton, 1964), 339-340.

${ }^{3}$ Jean-Paul Sartre, L'Être et le Néant, Essai d'ontologie phénoménologique (Paris: Gallimard, 1943).
} 
narrative techniques. I will start my argument with the above-quoted classical novel The Ambassadors (1903) by Henry James. Regarding the Polish realisations of James' technique, I shall consider a much later novel, Zasypie wszystko, zawieje [Everything Will Be Covered by the Snow] by Włodzimierz Odojewski (1973). The first-person version of the point of view technique is present also - in my opinion - in The Flanders Road by Claude Simon (1960). Finally, I will analyse a Polish novel from the $21^{\text {st }}$ century, namely Morfina [Morphine] by Szczepan Twardoch (2012).

\section{Jamesian roots of point of view}

The ironic opinion about an American provincial girl as quoted at the beginning of this paper is expressed by the main character in The Ambassadors. $\mathrm{He}$ also comes from the American province, but he has already succumbed to the charm of Paris and, at the end of the novel, he will poison himself with its remnants. This is how his point of view evolves, this is what Henry James, the creator of this technique, presents us with. Twenty years earlier James wrote in his essay The Art of Fiction: "I see dramas within dramas in that, and innumerable points of view." 4 There are as many of them as there are characters in the novel, and usually their accumulation determines the presence of drama in the novel's world. However, the formula developed in The Ambassadors lies not in the altercations and choices between different positions but in observing the world from one specific point of view, i.e. from Lambert Strether's consciousness.

In the preface to his earlier novel, What Maisie Knew, the writer stated: "The painter of life has indeed work cut out for him when a considerable part of life offers itself in the guise of that sapience." James, the painter of Lambert Strether's life, holds the brush with which he paints the story, but he relays the point of view to his character by providing him with knowledge gained through "the green spectacles." Told in the third person, the story of the "ambassador" traces the steps of a man coming to Europe from a small American town in order to talk some sense into a young citizen from his hometown who is - in his own family's eyes - immersed in Parisian debauchery, and to put him back on the righteous track and bring him back to America. The narrator does not go beyond Strether's illusions, who is otherwise an intelligent man but, like every

${ }^{4}$ James, "The Art of Fiction," in James, The Future of the Novel. Essays in the Art of Fiction, ed. Leon Edel (New York: Vintage Books, 1956), 23.

${ }^{5}$ James, "Preface to What Maisie Knew," in James, The Art of the Novel, ed. Richard Palmer Blackmur (New York: Charles Scribner's Sons, 1937), 149. In this text the narrowed point of view of a little girl is referred to as "my little vessel of consciousness." 
ambassador, he carries out someone else's mission. The novel ends in disappointment - despite the gossip spread throughout America the "ambassador" sees beauty and righteousness in everything, but, in fact, there is none of that - there is a relationship based on a public lie, which he does not find out about until the end of the novel, and when he does it happens only by coincidence. This is what is called "the guise of that sapience."

This is no place for a retelling of the story. The narrator is very discreet, although he makes no secret of the fact that he is the one telling the story and not one of the characters - as in the example below:

If we should go into all that occupied our friend in the watches of the night we should have to mend our pen; but an instance or two may mark for us the vividness with which he could remember. ${ }^{6}$

He writes ("paints") what "our character" sees, says, and experiences, but he does not judge - he leaves that to Strether's friends (who do not take the illusion away from him) and, more importantly, to the reader wandering on the outskirts of the character's consciousness. Perhaps he figures out that the subtext of the illusion is the experience of reading romantic novels? The character himself thinks, talks, and experiences the world. Even if he used to read romantic books he does not read them now and his only literary experience in this novel is the narration about the world surrounding him as created by the author.

Despite the fact that the point of view technique defined the poetics of The Ambassadors, a reflection on its construction is present in the preface to a novel that was published a year later, namely The Golden Bowl (1904). ${ }^{7}$ James mentions here a split of the narrative consciousness between the two characters and the abnormalities in the narration caused by doing so. However, in the preface to The Ambassadors James emphasises the point of view of one person only, i.e. Strether's. Nevertheless, third-person "figural narration" (this is how Franz Stanzel ${ }^{8}$ describes the poetics of this novel) is just one of the possible realisations of the point of view technique. In one of his theoretical works James writes about how his approach changed during his work on The Ambassadors, as the easiest way would have been to present the character's dilemmas by using first-person narration, just as in The Turn of the Screw. This is how he started the novel in 1903, yet he changed his mind, as a monologue would now represent a direct expansion of Strether's consciousness and emotions.

${ }^{6}$ James, The Ambassadors, 109-110.

${ }^{7}$ James, "Preface to The Golden Bowl," in James, The Art of the Novel.

${ }^{8}$ Franz Karl Stanzel, Narrative Situations in the Novel, trans. James P. Pusack (Bloomington: Indiana University Press, 1971, 
After all, his character "encaged and provided for as The Ambassadors encages and provides, has to keep in view proprieties much stiffer and more salutary than our straight and credulous gape are likely to bring home to him, has exhibitionistic conditions to meet, in a word, that forbid the terrible fluidity of self-revelation." ${ }^{9}$ Third-person narration allows to create a distance, i.e. a character sees and experiences but his or her passive consciousness evolves while communicating with others, depending on other people and, most of all, on other places that are different from America. Instead of talking about a fixed personality we are presented with a theatrical presentation, in which the personality evolves and becomes the main theme of the novel, so that at the end of the story the point of view is radically different. All of this is accomplished by describing the character's intuitions and his or her conversations with other characters by using free indirect speech.

\title{
2. From James to Odojewski: Towards interior monologue
}

James' point of view novel gains artistic and psychological confirmation in the preface; as well as an aesthetic one, a new form of realism makes the world visible, but it also commences to go beyond the narrator's control in favour of presentation through the character's eyes. In order to fully understand the revolutionary aspect of the point of view technique, it is useful to compare excerpts from two novels separated by over sixty years. Let us return to James where Lambert Strether meets Mrs. de Vionnet:

\begin{abstract}
This attitude fitted admirably into the stand he had privately taken about her connection with Chad on the last occasion of his seeing them together. It helped him to stick fast at the point he had then reached; it was there he had resolved that he would stick and at no moment since had it seemed as easy to do so. Unassailably innocent was a relation that could make one of the parties to it carry herself. If it wasn't innocent why did she haunt the churches? - into which, given the women he could believe he made out, she would never have come to flaunt an insolence of guilt. ${ }^{10}$
\end{abstract}

In the novel Zasypie wszystko, zawieje by Włodzimierz Odojewski, the narration expressed from the character's point of view is in the third person and it is accompanied by dialogue scenes, just as in James' works. Unlike his novels of manners, Odojewski's work has a serious, political character. And this is not the only difference. Over half a century of developing writing techniques changed the way of expressing the individual point of view. Below is an example of this trend:

\footnotetext{
${ }^{9}$ James, "Preface to The Ambassadors," in James, The Art of the Novel, 321.

${ }^{10}$ James, The Ambassadors, 120.
} 
He sat next to the cold fireside and, while looking at the particles of air sparkling in the sun, he tried to relax, although some voice was mumbling obtrusively inside his head, which could indeed be his own voice, but rather it was somebody else's, because it sounded out of place, whispering insistently, chaotically, and intricately, proving that "...she could answer for once at least something needs to be done with these dead bodies the Germans themselves take people there obviously to show us what will with us when they return go to hell only scavenger vultures firebugs and maggots will feast and only ashes soil and manure but still he wrote I'm healthy and everything's fine in Kozielsk obviously maybe he wrote not what he wanted but what he had to and before that you take care of her take care he said fine and his voice was like what about the suffering he imposed on her by leaving all ties he cut but what again with the suffering it's momentary now she surprised me she still remembers but not a word not a single teardrop tanned cute as if she was by the sea and what was she doing during those few days I will find out and more I will kill the whelp like what she was doing she won't tell that she was remembering her husband of course...," which he tried not to listen to, because what the voice was whispering obtrusively into his brain, it was biting him with deficient, shallow associations, but then a short breath of wind from the open windows went through the hall murmuring and clattered over his head. ${ }^{11}$

The experiences of the characters of these two novels, under which I understand their reactions to the behaviour of the women who fascinate them, are presented in a completely different manner. Although we penetrate their psyche in both novels, Strether's homogeneous yet evolving point of view strikes us as simple and concentrated on one subject, while in Odojewski's narration the behaviour of Paweł Woynowicz is presented from the third-person perspective, but his own thoughts are in the first person and put in quotation marks. The plain style of the first level contrasts with the chaotic interior monologue. Paweł thinks of several things at the same time, the image of a beautiful woman and her behaviour is juxtaposed with the image of the Katyn massacre, and the reader does not know whether it is a novel about love or about war until the very end. Throughout the text the narration is divided into two consciousnesses (Paweł's and Katarzyna's) that are revealed in two separate parts of the book and which present different visions of the same reality of the war. The tale about history transforms many times and becomes an incoherent stream of consciousness, which contrasts starkly with the classical prose of James. All of this is far from the psychological realism that was so appreciated by devotees of the American writer.

Yet Odojewski's innovative novel is not able to rid itself of the instruments of old objectivism. Much as in James' writing we come across the narrator's interventions, for example in the passage about Paweł hurrying to the partisans:

But if someone was looking at him from the above, one would know that he was marching unhesitatingly, with a spring in his step, but rather slowly at the same time... ${ }^{12}$

${ }^{11}$ Włodzimierz Odojewski, Zasypie wszystko, zawieje [Everything Will Be Covered by the Snow] (Warsaw: PIW, 1995), 28. Translation mine - K.P.

${ }^{12}$ Ibid., 304. 
Paweł sees himself and talks about himself and about everybody else - but who sees him? God? There is no mirror in this scene which could save the figural narrator. Also, the person who writes about Pawel is nowhere to be found; the author cannot (or he does not want to) deal with the material data about the world presented being restricted only to one standpoint. Sometimes he needs to add for example "him, Pawel" instead of leaving this to his rival Piotr. These "slips" transform into poetics in the prose of the nouveau roman.

Examining novels dominated by the narration narrowed to seeing the world from the character's perspective leads one to the conclusion that the nature of the point of view category is epistemological and that it can be realised via different techniques. The term "point of view" itself is usually replaced by other expressions (for instance "on her behalf" in The Ambassadors) or is entirely absent (the figural narration in Odojewski). Narrative studies add the action of talking to the category of seeing: a character who sees the fictional world in a certain way usually expresses his or her opinions through the dialogues and disputes with other characters. The above-quoted opinion by James on the multiplicity of points of view in various novels as well as in texts dominated by one or two points of view attached to the characters' consciousness (called the narrative media) proves the hypothesis about the variety of style. While the figural novel technique (despite the limitations of the narrator's interventions) does not need to be drastically different from authorial narration, stream of consciousness novels can present several different points of view that limit one another, as in Virginia Woolf's To the Lighthouse. ${ }^{13}$

\section{Claude Simon: Interplay of interior monologue and other voices}

Let us take a closer look at a text in which the character's point of view reveals itself through the stream of consciousness and his knowledge through pieces of information in the dustbin of memory, namely in The Flanders Road, a novel that was written in 1960 by Claude Simon.

The Flanders Road is an artistic construct which features both an epistemological standpoint of the point of view and a particular narrative technique, i.e. the internal monologue enriched with the statements of a large number of persons. All of these elements are located in the memory of the narrative medium, in this case a young French soldier fighting the Germans who attacked Poland on 1 September 1939 and who faced the French army in what was later

${ }^{13}$ Detailed knowledge on the varieties of points of view and their possible novel techniques is provided by Norman Friedman in "Point of View in Fiction. The Development of a Critical Concept," PMLA, vol. 70, no. 5 (1955), 1160-1184. 
known as the drôle de guerre. Georges recalls his experiences of the war but until the very end of the novel he does not understand it, as neither does he understand love or defeat - although war, love, and defeat are the main themes of the novel. Despite the fact that the point, or points, of view appear in Georges' speech and consciousness, these actions become dissolved in the reception of the book. It is difficult to call him a leading character - while this is possible in the case of the protagonists of either James or Odojewski. If it is the character who thinks and recalls the events, then there is no reason to rearrange what has been his for a long time. However, the character speaks - during a night of love he turns to the wife of his dead officer (almost all of the soldiers from his squadron died in Flanders as well), and five years after his war adventures he wants to talk to her about the officer's death. It is not clear whether he succeeds, because as Corinne sleeps he continues his chatter.

The double position of Georges, as a narrator and as a subject of his own stories, causes difficulty not only for readers but also for translators. For example the second chapter features a conversation between Georges and his companion regarding Fleming peasants. They talk about them on their way to the prison camp while recalling the events they had witnessed. Here I quote the original version and the English translation:

[...] c'est pour ça que ce fusil pourrait avoir envie de partir tout seul bon sang ce qu'il fait noir on arrive voilà la lumière

(trouvant les autres toujours assis en groupe autour de cheval agonissant, éclairés par la lanterne posee à même le sol, ils se retournent quand Georges et Blum entrent et leurs voix cessent, regardant un instant les arrivants, Georges se rendant compte alors qu'ils ont presque oublié le cheval, qu'ils le veillent comme à la campagne les vieilles femmes veillent les morts. ${ }^{14}$

[...] that's why that rifle could feel like going off by itself God it's dark

we're almost there there's the light

(finding the rest still sitting together around the dying horse, lit by a lantern set on the ground, they turned round while Georges and Blum came and their voices stopped, looking at the newcomers for a minute, Georges realizing then that they had almost forgotten about the horse, that they were sitting up with it like old women sit up with the dead in the country. ${ }^{15}$

The reader asks: Who is it that sees? Who tells what he sees in the first person? Is there another narrator who sees the peasants and Georges with Blum in the village and with the dead on their way to the prison camp at the same time? This impression is wrong, as it seems that it is still Georges but divided into three voices and three roles: that of the one observing the peasants, that of the one in the camp talking about them, and that of the one recalling with Corinne in 1946 both the peasants and the conversation. Both the gun and the

\footnotetext{
${ }^{14}$ Claude Simon, La route des Flandres (Paris: Les Éditions de Minuit, 1960), 110.

${ }^{15}$ Simon, The Flanders Road, trans. Richard Howard (New York: George Braziller, 1961), 129.
} 
horse belonged to her husband, who was already captain then, and the death of this officer, presumably a suicidal one, is the main theme of the story.

However, sometimes the author cannot resist adding something in order to make his readers understand who sees, who remembers, and who imagines. He writes:

Mais continue: après tout il n'est pas défendu de se figuirer que l'air expulsé par les boyaux remplis de bonne bière allemande qui fermente à l'intérieur de cette sentinelle fait entendre dans le concert général un moment de Mozart...» et Blum (ou Georges) : «C'est fini?» et Georges (ou Blum) : «Je pourrais continuer », et Blum (ou Georges) : «Alors continue », et Georges (ou Blum) : «Mais je dois également apporter ma contribution, participer, ajouter au tas, l'augmenter de quelquesunes de cette briquettes de charbon... » et Blum : «Bien, Donc cette loi qui veut que l'Histoire... ${ }^{16}$

But go on: after all there is no law against imagining that the air expelled by the bowels full of the good German beer fermenting in the guts, of that sentry produces, in the general concert a minuet by Mozart..." and Blum (or Georges): "Are you through," and Georges (or Blum): "I could go on," and Blum (or Georges): "So go on," and Georges (or Blum): "But I also must also bring my contribution, participate, add to the heap, augment it by some of those coal bricks," and Blum: "[...] probably by virtue of the law that states History..."17

And then he develops the main character's point of view.

Similar difficulties were experienced on numerous occasions by Odojewski, considered as the author of the nouveau roman in Polish.

That is why "postmodern" writers do not hide their own entanglements with the dilemmas and pitfalls of novelistic representation; moreover, instead of resolving these dilemmas they decide to mock them.

\section{Szczepan Twardoch: Parody of the point of view novel}

It is difficult to classify the narration in Szczepan Twardoch's Morfina as a nouveau roman. Its language is rather clear and its plot is coherent. The problem lies in the narrative structure. The inner monologue of the character and the dialogues with his companions are interrupted by comments in the second person by an odd character who introduces herself as "the black goddess" or "the grey, quiet, faceless friend." The main character's world, which he describes in the present or past tense, is enriched with facts from the future which he obviously cannot know or express. This impersonal character who interprets his actions does not possess the power of the omniscient narrator, although she

\footnotetext{
${ }^{16}$ Simon, La route des Flandres, 159-160.

${ }^{17}$ Simon, The Flanders Road, 190.
} 
indicates, on numerous occasions, that she is capable of telling Konstanty things that he will never know, so in a way she foresees his end. Her remarks are shy, frowning on his unawareness more than on his natural cynicism. In this way the narration becomes a grammatical and semantical medley. Let us reiterate: Konstanty Willeman, the main character, uses present and past tenses in the first person. The incorporeal phantom accompanying him refers to him in the second person:

Wonderfully, little thing, you took care of it wonderfully. You did Poland a double favour: the corpse with one eye gouged out and the head shot through will put the blame on the Germans, they will be responsible for this painful death. ${ }^{18}$

The grey friend, using the future or past tense, tells stories that Konstanty's mind could not fathom because he did not witness them, like in the passage about his mother's lovers, or because he was already dead, like in the passage about the death of the old maid Alicja in the east of Russia. Her remarks are often compassionate, although sometimes ironic or even auto-ironic:

There is truth in these stories, but do you think, little thing, that I care about the truth? Nevertheless, I wouldn't be able to tell the stories of everybody that you've ever met. ${ }^{19}$

And earlier:

To know that you'd need to know who you are, little thing. But I won't tell you this, because I don't know it myself, I've been looking at you for so long, my darling, and all I see is grey plasma, chaos. ${ }^{20}$

The plot of Morfina is built around the first days of World War II, much like the plot of The Flanders Road. We find ourselves in Warsaw, then in Cracow, Budapest, and again in Warsaw. The Polish underground resistance movement is counting on the support of France and downplays the defeat of the drôle de guerre. In the main character's eyes there is a "phoney war" taking place in Poland as well. Konstanty Willeman, dispatched on political missions, pretends to be a German (whom he is by birth), and as always there are women involved, there is much sex and, in the end, as in a typical war novel, the main character dies. He dies for two reasons. The murderer, Willeman's closest friend, shoots him because he was trying to win a woman's heart but, more importantly, and here the parodic tone of the novel can be found, he kills him

${ }^{18}$ Szczepan Twardoch, Morfina (Kraków: Wydawnictwo Literackie, 2012), 143. Translation mine - K.P.

${ }^{19}$ Ibid., 180.

${ }^{20}$ Ibid., 159. 
in the autumn of 1939 as ordered by the underground organisation Służba Zwycięstwa Polski. In this way he annihilates a hero who, against his own will, puts on a uniform belonging to his German father in order to fight for Poland. The absurdity of the situation is understood by Konstanty's incorporeal companion, who shows up at his side after the lethal shot. Her point of view is auto-ironic:

I loved you, Konstanty, and now I will love him, because I need to love someone, so I will love him, hollow and filled with despair. He will be dancing around prickly pears, after you've gone to the second kingdom of death, and I will be dancing with him. ${ }^{21}$

But the author makes the voice of the dying man heard just as the Old Masters did. Konstanty's last words, uttered from the underworld, are:

Nothing is because of nothing.

I need to pay the cabman. ${ }^{22}$

As I mentioned before, Morfina is a parody of the point of view novel. What is this based on? Pretending to be an authorial narration, "it reverses the directions" or "the orientation of the evaluative model." But via this parodistic reversal it also asks what the first object questioned by the point of view prose was, i.e. the authorial prose. The mysterious narrator draws a question mark over the actions of the narrators of the past - she does not believe in the psychological truth of the novel as she questions the order of the novelistic form. She does not rearrange anything by herself, although her utterances are full of crucial information. She also questions the "truth" about the war that was rejected. If Twardoch's novel tells a story about the beginning of World War II (and it does so very well indeed), then it also tells a story about the possibility of such a story.

Szczepan Twardoch decided to fight novel poetics by questioning its most recent achievements. By introducing the second-person narrator he also parodied different varieties of point of view prose. He accomplished all of this while writing a good novel about the very first days of World War II.

The above examples show four different, among many others, ways of employing the point of view technique which for more than a century has been a crucial theoretical and practical aspect of the novel. Its evolution is a part of the evolution of the genre.

\footnotetext{
${ }^{21}$ Ibid., 578.

${ }^{22}$ Ibid., 579.
} 


\section{Sum mary}

The article aims to analyse four important point of view novels, namely Henry James' The Ambassadors, Zasypie wszystko, zawieje [Everything Will Be Covered by the Snow] by Włodzimierz Odojewski, The Flanders Road by Claude Simon, and Morfina [Morphine] by Szczepan Twardoch. The notion of point of view serves as a starting point for considering the epistemological aspects of the novel and for tracing its evolution. James, both in his theory and novelistic practice, uses the point of view to make the character's consciousness the main theme of his novels. Odojewski employs internal monologue to render the characters' perspective, while Simon combines internal monologue with other voices. Finally, Twardoch's novel can be interpreted as a parody of the point of view technique.

\section{PUNKT WIDZENIA (W CZTERECH ODSŁONACH)}

\section{Streszczenie}

Celem artykułu jest analiza czterech ważnych powieści punktu widzenia: Ambasadorów Henry Jamesa, Zasypie wszystko, zawieje Włodzimierza Odojewskiego, Drogi przez Flandrię Claude’a Simona i Morfiny Szczepana Twardocha. Kategoria punktu widzenia służy jako punkt wyjścia refleksji nad mechanizmami poznania w powieści. Umożliwia również prześledzenie ewolucji techniki, od klasycznych Jamesowskich realizacji jego autorskiej koncepcji punktu widzenia, poprzez monolog wewnętrzny Odojewskiego, u Simona łączony z głosami cudzymi, do powieści Twardocha, która może być traktowana jako parodia powieści punktu widzenia. 